\title{
Influence of grazing, vegetation life-form, and soil type on infiltration rates and interrill erosion on a Somalion rangeland
}

\author{
A.A. TAKAR, J.P. DOBROWOLSKI, AND T.L. THUROW
}

\section{Abstract}

Heavy communal grazing pressure and rapid phytomass decomposition reduce shrub interspace cover in Somalia from $100 \%$ at the end of the growing season to $5 \%$ at the end of the dormant season. Intense monsoonal rains, characteristic of Somalia and other areas of subsaharan Africa, combined with sparse vegetative cover at the beginning of the rainy season, may result in overland flow and excessive erosion, even where sand content of the soil exceeds $90 \%$. Little watershed research has been conducted in this region other than to document that the problem is extreme. The objectives of this study were to assess the seasonal hydrologic responses as influenced by 2 soils (sand vs. clay), grazing intensity (exclusion vs. heavy communal grazing), and cover types (shrub understory vs. interspace) in Somalia. Infiltration rate and interrill erosion on the sand site were significantly greater than on the clay site regardless of cover type or season. The clay site was dominated by annual forbs which rapidly decomposed. The sand site had greater annual and perennial grass cover which decomposed slower than forbs, providing longer and perhaps better protection from raindrop impact energy. Three growing seasons of livestock exclusion did not significantly increase soil cover on shrub interspaces; consequently, infiltration rates and interrill erosion remained similar to the communally grazed sites. Interspace cover left by livestock was instead removed by termites and other microorganisms. Restricted ability of livestock to graze beneath thorny shrubs and increased phytomass from shrub leaf-fall resulted in a greater accumulation of cover and litter beneath shrubs, which aided infiltration on clay sites, regardless of season.

Key Words: watershed management, wildland hydrology, communal grazing

The factors determining runoff and erosion are a consequence of complex interactions of vegetation and soil characteristics (Thurow et al. 1986). Hydrologic condition is reflected by infiltration rate and interrill erosion, which integrate these soil and vegetation factors. Grazing intensity has been shown to alter surface soil and vegetation characteristics on a variety of sites and plant communities (Blackburn et al. 1982). The livestock populations in Somalia have grown in an attempt to meet the needs of the enlarging pastoral human population. This has resulted in an increased frequency and intensity of grazing which may result in a decline of relative stability between disturbance and resource recovery (Warren et al. 1986a).

A decrease in cover and a shift in composition from shrubs and perennial grasses to annual grasses and forbs has been documented to occur as grazing intensity increases in central Somalia (Herlocker et al. 1987, 1988). Successional trends in plant communities are proportional to grazing intensity, with most severe changes occurring under heavy grazing (Ellison 1960). Hydrologic charac-

\footnotetext{
Authors are former graduate research assistant, assistant professor of rangeland hydrology, Department of Range Science and Watershed Science Unit, Utah State University, Logan 84322-5230; and assistant professor of watershed management, Department of Range Science, Texas A\&M University, College Station 77843 .

This research was supported by the Utah Agricultural Experiment Station, Utah State University, Logan $84322-4845$. This study was funded as part of the Somali Central Rangeland Development Project, USDA/Somalia Project 649-0108. The assistance of A.J. Hussein and M.A. Ahmed in the data collection is acknowledged. Manuscript accepted 17 April 1990.
}

teristics of rangelands are generally positively related to vegetatal cover and standing crop (Blackburn 1984). Vegetation growth form is also an important determinant of rangeland hydrology, with runoff and erosion lowest under trees and shrubs, followed in decreasing order by bunchgrasses, sodgrasses, and bare ground (Blackburn 1975, Thurow et al. 1986). Compositional shifts resulting in the removal of perennial plants are especially important indicators of range condition (Dyksterhuis 1949) because their decline is usually associated with increased erosion (Walker 1974). Seasonal variability in precipitation may interact with grazing to alter the hydrologic condition of rangeland (Warren et al. 1986a). Trampling moist soils has been shown to reduce infiltration rates by promoting surface soil compaction (Edmond 1962, Lull 1959, Warren et al. 1986b) and surface sealing (Beckmann and Smith 1974).

Management of communal grazing lands throughout arid and semiarid Africa is affected by a series of factors that make soil and water conservation particularly difficult. Even though the region is arid to semiarid, periodic flooding associated with monsoonal rainfall occurs causing severe water erosion. Little rangeland watershed research has been conducted in subsaharan Africa other than to document that the problem is extreme. Ethiopia is estimated to lose 1-3 billion tons of topsoil every year; Lesotho's average soil depth has been reduced from $38 \mathrm{~cm}$ to $28 \mathrm{~cm}$ during this century; Zimbabwe is estimated to annually lose 1.5 million tons of nitrogen, 15.6 million tons of organic matter, and 0.24 million tons of phosphorus, from soil erosion (Ayoub 1988).

Somalia shares many characteristics common to the subsaharan region. A combination of monsoonal rainfall, heavy grazing pressure (Thurow et al. 1989), and rapid phytomass decomposition (Thurow 1989) cause organic cover to range from near $100 \%$ at the end of the growing season to $5 \%$ at the end of the dormant season (Thurow and Hussein 1989). Intense storms combined with sparse vegetatal cover at the beginning of the rainy season may result in overland flow and erosion even where the percent sand content exceeds $90 \%$. The objectives of this research were to assess the seasonal hydrologic responses as influenced by soil type, grazing intensity, and vegetation life form on a Somali rangeland.

\section{Study Area}

The study was conducted $8 \mathrm{~km}$ southeast of Afgoi, Somalia ( $2^{\circ}$ $10^{\prime} \mathrm{N}, 45^{\circ} 05^{\prime} \mathrm{E}$ ). Meteorological data were collected at a permanent station located $3 \mathrm{~km}$ east of the study site. Precipitation is bimodal, with significant rainfall restricted to April-June and October-December. Annual precipitation at the study site was highly variable (annual median precipitation, 1981 to $1987=446$ $\mathrm{mm}$; range $=214$ to $670 \mathrm{~mm}$ ). Precipitation within the rainy season was typically clumped into several periods of intense storms (e.g., the maximum consecutive 5-day period of rainfall for any particular year averaged $22 \%$ of annual precipitation). Mean monthly temperatures ranged from 25 to $30^{\circ} \mathrm{C}$. Annual precipitation was 3 to $20 \%$ of evaporative demand (UNSO 1984).

Research was conducted on $\mathbf{2}$ of the dominant rangeland soil types in Somalia. The clay site was a fine-textured, dark brown Grumosol of the Goluen series (FAO 1968, Bahdon et al. 1986). 
The soil had developed from recent alluvium of the Shabelle River flood plain. Most native savanna on this soil type has been cleared for cultivation. The sand site was composed of aeolian and marine sediments, ranging in texture from sand at the surface to sandy loam at a depth of $1 \mathrm{~m}$ and showing little horizon development.

Shrubs on the study site had a clumped distribution, with the shrub interspaces vegetated by herbaceous grasses and forbs. Shrub cover varied from 30-50\% over the study area (Ibrahim and Barker 1986). Dominant shrub species were Acacia tortilis (Forsk) Hayne, Acacia horrida (L.) Willd., and Dichrostachys kirkii Benth. Herbaceous cover was dominated by the annual forbs Commelina forskalaei Vahl, Indigofera tinctoria L., and Ipomoea garckeana Vatke, and grasses Cenchrus ciliaris L., Eragrostis ciliaris (L.) R. Br. and Leptothrium senegalense (Knuth) W.D. Clayton.

\section{Methods}

Infiltration rates, interrill erosion, cover characteristics, vegetation standing crop, mulch accumulation, and surface soil physical properties were sampled in March (end of the dry season) and May ( 2 weeks after the wet season began), 1987. Samples were collected under shrubs and in the shrub interspaces on each of 3 different sites: sand textured soil that was communally grazed unfenced rangeland (CGS), sand textured soil in a 2-ha livestock exclosure that had been in place for 3 growing seasons (UGS), and a clay textured soil that was communally grazed unfenced rangeland (CGC). It was not possible to replicate a livestock exclosure on the clay soil site due to cultural land use restrictions. The grazed sites were grazed heavily with cattle and goats herded by seminomadic pastoralists at an approximate stocking rate of $5 \mathrm{ha} \mathrm{au}^{-1} \mathrm{yr}^{-1}$ (Thurow and Hussein 1988).

During each sample period ten $0.65-\mathrm{m}^{2}$ plots were randomly located at each of the 3 sites and in each of the 2 vegetation types (i.e., shrub understory and shrub interspaces). Plots were pre-wet by applying $100 \mathrm{l}$ of water using a gravity sprinkler system over a $1-\mathrm{m}^{2}$ circular area. Plots were covered with plastic sheeting for about 18 hours. This procedure was used to bring all plots to approximately field capacity and reduce the variability in antecedent soil moisture that would have occurred between sample dates. This facilitated analysis across time. Pre-wetting the plots is particularly applicable in Somalia because several days of light rains usually precede intense storms of the rainy season.

Infiltration rates and interrill erosion were determined with a modular drop-forming rainfall simulator (Chow and Harbough 1965), as modified by Malekuti and Gifford (1978). Simulated raindrops were $2.5 \mathrm{~mm}$ in diameter and collectively reached about $60 \%$ of the terminal velocity achieved by raindrops in an unlimited fall (Laws 1941). The simulated rainfall was applied at a rate of 170 $\mathrm{mm} \mathrm{h}^{-1}$ for 45 -min (equivalent natural return interval not available). This intensity was chosen to simulate the intense monsoonal storms which predominate during Somalia's rainy seasons and to ensure that all plots would approach an infiltration constant. This criterion was desirable so that constant infiltration rates could be compared between soil sites, grazing treatments and cover types.

Runoff was continuously collected from each plot and was recorded by volume at 5 -min intervals. Infiltration was calculated as the difference between applied rainfall and measured runoff $\left(\mathrm{mm} \mathrm{h}^{-1}\right)$. A 1-liter subsample of thoroughly mixed runoff was collected at the conclusion of the 45-min sample periods. Each subsample was filtered through a tared \#1 Whatman filter. Sediment remaining on the filter was oven-dried, weighed, and converted to sediment production $\left(\mathrm{kg} \mathrm{ha}^{-1}\right)$.

Soil cores at $0-50 \mathrm{~mm}$ and $50-100 \mathrm{~mm}$ depths were taken from immediately outside the runoff plots prior to the start of the simulated rainfall. These cores were used to determine soil bulk density by the core method (Blake and Hartge 1986) and soil water content by the gravimetric method (Gardner 1986).

The percentage and type of surface cover on each runoff plot was determined by ocular estimate. After rainfall simulation, standing crop of grasses and forbs was clipped to the soil surface, and litter was removed from each plot. The vegetatal samples and litter were dried separately at $60^{\circ} \mathrm{C}$ for $24 \mathrm{~h}$, weighed, and converted to $\mathrm{kg}$ $\mathrm{ha}^{-1}$.

Surface soil samples (0-50 $\mathrm{mm}$ depth) were taken from within each plot following the rainfall simulation event. Particle size distribution of the soil samples was determined by the pipette method (Gee and Bauder 1986). Organic matter content was determined by the Walkley-Black method (Nelson and Sommers 1982).

The experiment was designed as a completely randomized $2 \times 3$ $\times 2$ factorial (season, soil/grazing, and shrub/interspace). Without spatially interspersed replication, statistical procedures used to analyze data from grazed and ungrazed conditions were interpreted under the assumption of pseudoreplication (Hurlbert 1984). Mean square error (MSE) residuals were tested for normality and the data were transformed when necessary. Values for interrill erosion required a $\log _{10}$ transformation. Treatment differences were determined using analysis of variance $(p \leq 0.05)$. Treatment means were separated by Fisher's protected least significant difference (LSD). Simple linear correlation analysis determined the degree of association between dependent variables (infiltration rate and interrill erosion) and regressor variables (soil and vegetation characteristics). Correlations were considered significant at $\mathrm{p} \leq \mathbf{0 . 0 5}$ ). Forward stepwise multiple regression (entry and stay level $p \leq 0.05$ and $p<0.15$, respectively) was used to identify the most important set of variables influencing infiltration rate and interrill erosion (Draper and Smith 1981).

\section{Results and Discussion}

\section{Infiltration}

Infiltration rates gradually declined during the first $35 \mathrm{~min}$ of the simulated rainfall but then increased slightly for the last 10 minutes of the application (Fig. 1). Greater infiltration towards the end of simulated rainfall was consistent across treatments and could not be attributed to simulated rainfall application or measurement error. Excavation of the surface horizon exposed a thin cemented soil layer that varied in depth from 10 to $30 \mathrm{~cm}$ below the soil surface. Analysis of calcium carbonate in this layer revealed

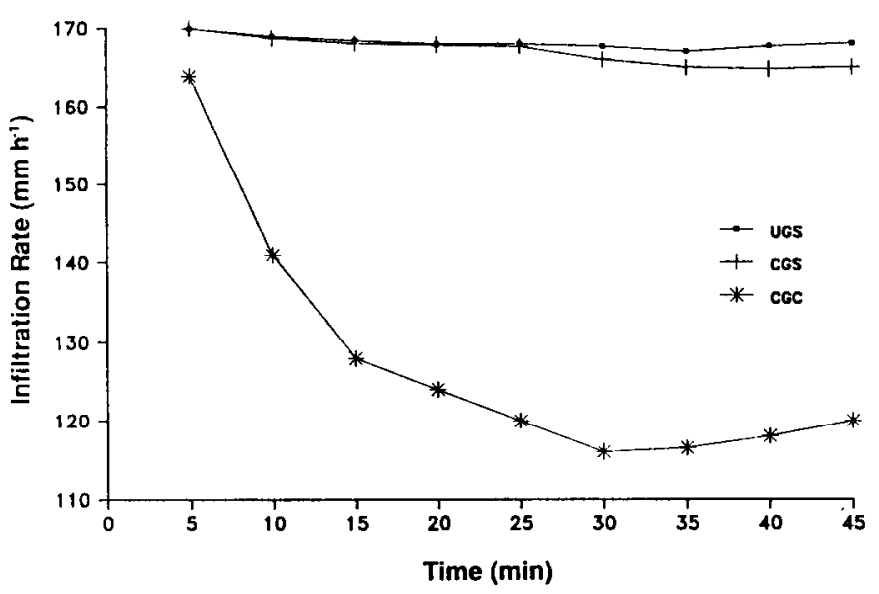

Fig. 1. Mean infiltration rate on communally grazed sand site (CGS), communally grazed clay site (CGC) and ungrazed sand site (UGS) across the $45 \mathrm{~min}$ simulated rainfall application, Afgoi, Somalia. 
slightly higher concentrations (sand site $=1.3 \%$; clay site $=14.3 \%$ ) than were present in the overlaying soil (sand site = undetectable; clay site $=13.1 \%$ ). . Calcified soil may result from the combination of aeolian deposited calcium and clean sand producing carbonated grains capable of restricting water percolation (Goudie 1973). An accumulation of organic chemicals leached to this depth may also have contributed to the observed soil cementation (DeBano 1981). During the early part of the rainfall simulation event, the upper soil layer may have become saturated, reducing the infiltration rate. The combination of hydraulic head pressure and dissolution of the cemented layer may have provided the conditions for improved infiltration near the end of rainfall period. Mean infiltration rate after 45 min displayed the greatest correlation with other measured variables; thus it is the only infiltration rate variable considered in the following discussion.

Infiltration rate was significantly greater on the sandy soil than the clayey soil regardless of cover type or season (Fig. 2). Similar

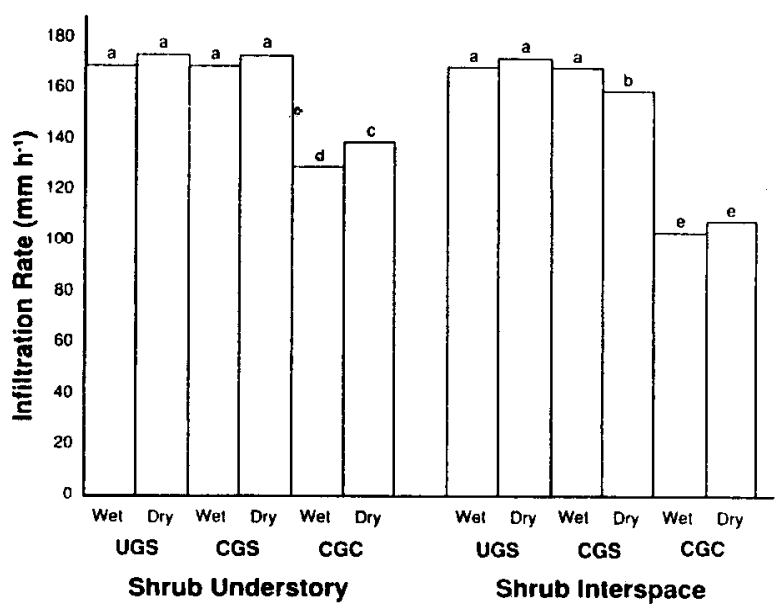

Fig. 2. Mean infiltration rate for ungrened send site (UGS), communally grazed sand site (CGS) and communally grazed clay site (CGC) seasons and cover types, Afgoi, Somalia. Means with the same letter are not significantly different $(P \leq 0.05)$.

differences in hydrologic response between surface soil textures have been noted by Rauzi et al. (1968). A sand-dominated soil may contain large pores which promote rapid soil water drainage and tends to armor the soil surface against slaking and sealing. The combined effect of large pores and resistance to dispersion aids infiltration (Renard et al. 1974). Silt and clay-dominated soil with little organic matter content may have much smaller pores, creating a more tortuous path for water inflow. In uncrusted soils, silt and clay particles are also smaller and more easily detached by raindrops than larger sand particles. The micropores on silt and clay sites may become clogged more quickly than on sand sites when exposed to raindrop impact, resulting in increased runoff (Cary and Evans 1974). The proportion of silt and clay in the soil surface was negatively correlated with infiltration rate $(r=-0.89$ for both soil types).

Infiltration rate on the sand site showed no difference associated with grazing. The exclosure had greater phytomass and grass cover than the communally grazed site but there was no significant difference in the percentage of bare ground. The small influence of grazing exclusion on percentage of bare ground is in part due to activity of termites and other microfauna ( $94 \%$ decomposition within 1 year) (Thurow 1989). The lack of difference between the exclosure and the grazed area may be due to the relatively short time ( 3 years) that the ungrazed area was excluded from grazing. If grazing pressure was as high before exclusion as it appeared to be on the grazed area, the entire area may have been in a serious state of depletion. Recovery from that condition may take 10 years or more to manifest itself. Therefore, quick response to management may not be expected. Other vegetal variables were not significantly different between grazing treatments on the sand site. Soil physical and chemical factors were unchanged as a result of grazing exclusion.

Infiltration rates of shrub understories and interspaces were not significantly different, regardless of season, on the sandy soil site within the livestock exclosure; outside of the exclosure shrub understory plots had greater infiltration rates than interspace areas but only during the dry season. On the clay site significantly greater infiltration occurred on shrub understory plots compared with interspaces during both wet and dry seasons. The different response of infiltration rate in the shrub understory is, at least in part, due to differences in litter accumulation. On the grazed sites litter and organic matter content were significantly greater beneath shrubs when compared to interspaces, primarily because the interspaces were heavily grazed while livestock were not able to graze as effectively under the thorny shrubs. In the livestock exclosure litter accumulated in the interspace to a level similar to that under the shrubs. Differential accumulation under the shrub and the interspace was apparently moderated by termite activity. Litter promotes detention storage of surface runoff and adds decomposed material to the organic matter reservoir in the soil surface. Organic matter content is correlated with water stable aggregate stability which is, in turn, positively correlated to infiltration rate (Oades 1984). These characteristics acting in concert or individually promote water infiltration beneath shrubs (Blackburn 1975, Branson et al. 1981, Thurow et al. 1986, and Eckert et al. 1986). The greater infiltration rate associated with soil under shrubs implies a potential benefit from the establishment and perpetuation of the shrubs in the region. The greater infiltration rate beneath shrubs could accommodate the added water flowing off the shrub interspaces during periods of intense rainfall, thus reducing the risks of excessive erosion, flooding, and sedimentation.

The clay site had a greater infiltration rate during the dry season compared to wet season. Surface litter cover decreased during the wet season, presumbly through moisture-accelerated decomposition and increased microfauna activity. Exposed bare soil declined slightly from dry to wet seasons on the clay site. However, the greater plant cover did not improve infiltration characteristics to the point of compensating for the simultaneous decline in litter.

Stepwise regression analysis was used to identify the set of measured variables that most effectively predicted infiltration rate. The following model $\left(R^{2}=0.88\right)$ was de"reloped:

Mean Infiltration Rate after $45 \mathrm{~min}\left(\mathrm{~mm} \mathrm{~h}^{-1}\right)=114.3+0.001$ (litter biomass, $\mathrm{kg} \mathrm{ha}^{-1}$ ) +0.64 (sand content at $0-50 \mathrm{~mm}$ depth, \%) -0.30 (bare ground cover, \%).

The predictive capability of the model was not increased when additional variables were included. Simple linear correlation revealed that infiltration rate was directly related to the sand fraction of the surface soil and above-ground litter biomass ( $r=$ 0.89 and 0.30 , respectively). A negative relationship existed between percent bare ground and infiltration rate $(r=-0.33)$. Exposed mineral soil may slake when subjected to the beating action of raindrops, forming a transient surface seal and thereby reducing infiltration rates. Visual evidence of crusting was clearly evident on the clay sites, particularly in shrub interspaces. Surface litter intercepts raindrops and may reduce the impact energy important in soil slaking and sealing processes. It may also provide for greater water detention storage on the surface. 


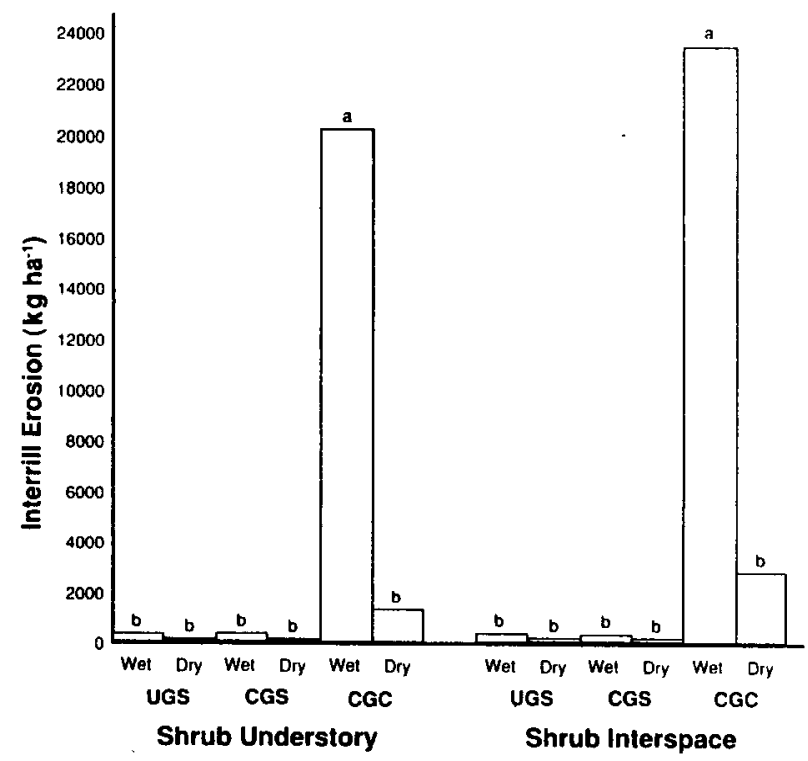

Fig. 3. Mean interrill erosion for ungrazed sand site (UGS), communally grazed sand site (CGS) and communally grazed clay site (CGC) seasons and cover types, Afgoi, Somalia. Means with the same letter are not significantly different $(p \leq .05)$

\section{Interrill Erosion}

Interrill erosion varied little between sites or seasons, with the notable exception being on the clay site during the wet season (Fig. $3)$. The reason is explained by examination of the variables in the model $\left(R^{2}=0.75\right)$ which were determined to be most effective for predicting interrill erosion:

Mean interrill erosion $\left(\mathrm{kg} \mathrm{ha}^{-1}\right)=5.33+0.0004$ (grass phytomass, $\mathrm{kg} \mathrm{ha}^{-1}$ )0.02 (litter cover, \%) - 0.02 (grass cover, \%) - 0.04 (sand, \%)

Correlation analysis showed grass standing crop and grass cover were weakly related to interrill erosion $(r=-0.20$ and -0.26 , respectively). Surface characteristics such as vegetatal cover, which tend to promote infiltration and control rain splash and runoff, will reduce interrill erosion (Marshall and Holmes 1979). Grass cover (primarily Eragrostis ciliaris) increased by a factor of 20 from dry to wet seasons on the sand sites. No significant increase in grass cover occurred on the clay site; rather, single-stemmed forbs dominated. Poorer interception characteristics of forbs $(20-60 \%$ interception for prairie forbs vs. $50-80 \%$ for perennial grasses, [Clark 1940]) and less obstruction to overland transport of sediment provided by single-stemmed forbs compared to multi-stemmed grass may account for greater sediment loss. Forb litter decomposed much more rapidly than grass litter (Thurow 1989) accounting for differential litter cover between the sites. Soil physical characteristics were found to be more strongly associated with interrill erosion than surface cover. Interrill erosion was negatively correlated with the sand fraction of the surface soil $(r=-0.64)$ and was positively correlated with silt $(r=0.68)$ and clay $(r=0.62)$. These findings are consistent with similar relationships reported by Renard et al. (1974).

\section{Conclusions}

Hydrologic characteristics of range sites and associated land use should be an important consideration when formulating rangeland development plans. Intense monsoonal rainfall combined with rapid removal of vegetatal cover creates an environment suscepti- ble to flash-flooding and erosion. Three growing seasons of livestock deferment did not significantly increase cover remaining on the shrub interspaces at the end of the dry season. Cover left by livestock was later removed by termites and other microorganisms. The lack of cover difference between grazed and ungrazed sites resulted in similar infiltration rates and interrill erosion. Decreased ability of livestock to graze under the thorny shrubs and greater phytomass associated with shrub leaf-fall accounts for the greater cover and litter biomass accumulation in the shrub understory which aided infiltration rates.

The clay site had a lower infiltration rate and greater interrill erosion than the sand site. This was attributable to characteristics of the clay soil. Also, the clay sites were more dominated by annual forbs. The different cover characteristics of forbs, compared with the greater cover of annual grasses on the sandy site, and the rapid decomposition associated with forbs, contributed to greater seasonal variability of infiltration and interrill erosion on the clay site. For these reasons the clay sites represent a source of proportionally greater danger in terms of runoff and erosion, which should be a consideration in the management of these arid rangelands.

\section{Literature Cited}

Ayoub, A.T. 1988. Land for food security in Africa. Desertification Control Bull. 17:27-29.

Bahdon, J.A., A.A. Takar, and A.A. Yasin. 1986. Evaluation of the characteristics of some soil series common in central Somalia. Somali J. Range Sci. 1:11-13.

Beckmann, G.G. and K.J. Smith. 1974. Micromorphological changes in surface soils following wetting, drying and trampling, p. 832-845. In: G.K. Rutherford (ed.), Soil microscopy: Proceedings of the 4th international working-meeting on soil micromorphology. Limestone Press, Kingston, Ontario.

Blackburn, W.H. 1975. Factors influencing infiltration and sediment production of semi-arid rangelands of Nevada. Water Resour. Res. 11:929-937.

Blackburn, W.H. 1984. Impacts of grazing intensity and specialized grazing systems on watershed characteristics and responses, p. 927-983. In: Developing Strategies for Rangeland Management. Nat. Res. Coun. /Nat. Acad. Sci., Westview Press, Boulder.

Blackburn, W.H., R.W. Knight, and M.K. Wood. 1982. Impact of grazing on watersheds: A state of knowledge. Texas Agr. Exp. Sta. Pub. MP-1496.

Blake, G.R., and K.H. Hartge. 1986. Bulk density, p. 383-409. In: A. Klute (ed.), Methods of soil analysis. Part 1, Physical and mineralogical methods. Agronomy Series No. 9, Agron. Soc. Amer., Madison, Wis.

Branson, F.A., G.F. Gifford, K.G. Renard, and R.F. Hadley. 1981. Rangeland hydrology. Kendall/ Hunt Publ. Co., Dubuque, Iowa.

Cary, J.W., and D.D. Evans. 1974. The influence of soil crusts on heat and water storage, p. 45-55. In: J.W. Cary and D.D. Evans (eds.) Soil crusts. Univ. Arizona Agr. Exp. Sta. Tech. Bull. 214.

Clark, O.R. 1940. Interception of rainfall by prairie grasses, weeds, and certain crop plants. Ecol. Monogr. 10:243-277.

Chow, V.T., and T.E. Harbough. 1965. Raindrop production for laboratory watershed experimentation. J. Geophys. Res. 70:6111-6120.

DeBano, L.F. 1981. Water repellent soils: a state-of-the-art. USDA, Forest Serv. Gen. Tech. Rep. PSW-46.

Draper, N.R., and H. Smith. 1981. Applied regression analysis. John Wiley and Sons, Inc., New York.

Dyksterhuis, E.J. 1949. Condition and management of rangeland based on quantitative ecology. J. Range Manage. 2:104-115.

Eckert, R.E. Jr., F.F. Peterson, and J.T. Belton. 1986. Relation between ecological range condition and proportion of soil surface types. J. Range Manage. 39:409-414.

Edmond, D.B. 1962. Effects of treading pasture in summer under different soil moisture levels. N.Z. J. Agr. Res. 5:389-395.

Ellison, L. 1960. Influence of grazing on plant succession of rangelands. Bot. Rev. 26:1-78.

FAO. 1968. Agricultural and water surveys: Somalia. Final Report, Rome. Gardner, W.H. 1986. Water content, p. 493-541. In: A. Klute (ed.), Methods of soil analysis. Part 1, Physical and mineralogical methods. Agronomy Series No. 9, Agron. Soc. Amer., Madison, Wis. 
Gee, G.W., and J.W. Bauder. 1986. Particle-size analysis, p. 399-404. In: A Klute (ed.), Methods of soil analysis. Part 1, Physical and mineralogical methods. Agronomy Series No. 9, Agron. Soc. Amer., Madison, Wis.

Goudie, A. 1973. Duricrusts in tropical and subtropical landscapes. Clarendon Press, Oxford.

Herlocker, D.J., A.M. Ahmed, and T.L. Thurow. 1987. Response of vegetation of the Acacia reficiens/Dichrostachys kirkii shrubland range site to land use intensity, Ceel Dhere District, Somaia. Somali J. Range Sci. 2:10-24.

Herlocker, D.J., A.M. Ahmed, and T.L. Thurow. 1988. Response of vegetation of the Acacia nilotica/Dichrostachys kirkii shrubland range site to land use intensity, Ceel Dhere District,Somalia. Somali J. Range Sci. 3:1-11.

Hurlbert, S.H. 1984. Pseudoreplication and the design of ecological field experiments. Ecol. Monogr. 54:187-211.

Ibrahim, M.A., and J.R. Barker. 1986. Pattern of acacia distribution on a ranch near Afgoi, Somalia. Somali J. Range Sci. 1:27-30.

Laws, J.O. 1941. Measurement of the fall-velocity of water-drops and raindrops. Trans. Amer. Geophys. Union 22:709-721.

Lull, H.W. 1959. Soil compaction on forest and range lands. USDA Misc. Pub. 768.

Malekuti, A., and G.F. Gifford. 1978. Natural vegetation as a source of diffuse salt within the Colorado River Basin. Water Resour. Bull. 14:195-205.

Marshall, T.J., and J.W. Holmes. 1979. Soil physics. Cambridge Univ. Press, Cambridge.

Nelson, D.W., and L.E. Sommers. 1982. Total carbon, organic carbon, and organic matter, p. 539-577. In: A.L. Page, R.H. Miller, and D.R. Keeney (eds.), Methods of soil analysis. Part 2, Chemical and microbiological properties. Agronomy Series, No. 9, Agron. Soc. Amer., Madison, Wis.
Oades, J.M. 1984. Soil organic matter and structural stability: mechanisms and implications for management. Plant Soil 76:319-337.

Rauxi, F.C., C.L. Fly, and E.J. Dyksterhuis. 1968. Water intake on Midcontinental rangelands as influenced by soil and plant cover. USDA Tech. Bull. 1390.

Renard, K.G., J.R. Simanton, and H.B. Osborn. 1974. Applicability of the universal soil loss equation to semiarid rangeland conditions. Proc. Hydrology and Water Resour. in Ariz. and the Southwest. Amer. Water Resour. Assoc., Arizona Acad. Sci. 4:18-32.

Thurow, T.L., W.H. Blackburn, and C.A. Taylor, Jr. 1986. Hydrologic characteristics of vegetation types as affected by livestock grazing systems, Edwards Plateau, Texas. J. Range Manage. 39:505-509.

Thurow, T.L., and A.J. Hussein. 1989. Observations on vegetation responses to improved grazing systems in Somalia. J. Range Manage. 42:16-19.

Thurow, T.L., D.J. Herlocker, and A.A. Elmi. 1989. Development projects and Somali pastoralism. Rangelands 11:35-39.

Thurow, T.L. 1989. Decomposition of grasses and forbs in coastal savanna of southern Somalia. Afr. J. Ecol. 27:201-206.

United Nations Sahelian Office (UNSO). 1984. Inventory of sand movement in Somalia. UNSO/DES/SOM/80/110.

Walker, B.H. 1974. Ecological considerations in the management of semiarid ecosystems in South-Central Africa. p. 124-129. In: Proc 1st Int. Congr. Ecol. Centre Agr. Yub. Doc., Wageningen, The Netherlands.

Warren, S.D., W.H. Blackburn, and C.A. Taylor. 1986a. Effects of season and stage of rotation cycle on hydrologic condition of rangeland under intensive rotation grazing. J. Range Manage. 39:486-491.

Warren, S.D., T.L. Thurow, W.H. Blackburn, and N.E. Garza. 1986b. The influence of livestock trampling under intensive rotation grazing on soil hydrologic characteristics. J. Range Manage. 39:491-495.
Commonwealth Bureau of

Pastures and Field Crops

Hurley, Maidenhead,

Berks SL6 5LR, UK
For specimen copies of these computer-produced monthly journals and for lists of annotated bibliographies and other publications write to

\section{HERBAGE ABSTRACTS}

(grasses, pastures, rangelands, and fodder crops)

\section{FIELD CROP ABSTRACTS}

(annual field crops)

for coverage of the world literature on agricultural research 